\title{
Phyllody Phytoplasma infecting Sesame (Sesamum indicum) in Myanmar
}

\author{
Nang Kyu Kyu Win, Chang-Gi Back \& Hee-Young Jung \\ Division of Applied Biology and Chemistry, Kyungpook National University, Daegu 702-701, Korea
}

Author for correspondence: Jung Hee-Young, email: heeyoung@knu.ac.kr

\begin{abstract}
Phyllody symptoms in sesame plants consisting of green leaf-like floral organs were collected from Yezin area, NayPyiTaw Division, Myanmar in January, 2010 and the etiological agent was investigated. By using Polymerase Chain Reaction (PCR), phytoplasma was detected from the symptoms and termed sesame phyllody phytoplasma (SP-MYAN). Restriction Fragment Length Polymorphism (RFLP) analysis of $16 \mathrm{~S}$ rDNA products revealed that the diseased sesames were infected by phytoplasma belonging to the group $16 \mathrm{SrI}$ and subgroup 16SrI-B. Sequence analysis confirmed that SP-MYAN was a member of Candidatus Phytoplasma asteris and most closely related to that of sesame phyllody phytoplasma from India (99.6 \% similarity, DQ431843), Ca. P. asteris strain. To our knowledge, this is the first report on molecular identification of ' $\mathrm{Ca}$. P. asteris' affecting sesame crop in Myanmar.
\end{abstract}

Key words: Candidatus Phytoplasma asteris, Sesame phyllody, 16S rDNA sequence

Sesame is one of the major oil seed crops in Myanmar. Myanmar is the third most important sesame producer in the world and accounts for $7 \%$ of global production after India and China (Favre \& Kyaw Myint, 2009). Sesame phyllody (SP), caused by phloemlimiting phytoplasmas, is primarily distributed in the tropical countries including Asia and Africa (McCoy et al., 1989; Nakashima et al., 1999) and also present in neighboring countries like Thailand (Nakashima et al., 1995) and India (Khan et al., 2007). The disease is characterized by virescence, phyllody, yellowing, floral sterility and stem proliferation of infected plants (Akhtar et al., 2008) and causes seed yield loss up to 33.9 percent (Abraham et al., 1977). SP disease has also been found in Myanmar for a number of years in sesame fields; however, prior to this report the causal agent had not been identified systematically. The present study reports on the identification and molecular characterization of phytoplasma associated with sesame phyllody in Myanmar based on 16S ribosomal DNA sequence analysis.

Five symptomatic samples including virescence were collected from infected sesame fields around yjr Yezin area, NayPyiTaw Division, Myanmar in January, 2010 (Figure 1). Total DNAs were extracted by using cetyl trimethyl ammonium bromide (CTAB) method described by Namba et al. (1993). The presence of phytoplasma in symptomatic samples was determined by Polymerase Chain Reaction (PCR) procedure using a universal set of primers SN910601 and SN011119 designed by Jung et al. (2003). Amplification was performed in an automated thermal cycler programmed for one cycle of $94^{\circ} \mathrm{C}$ for 5 minutes followed by 35 cycle reaction profile involving 30 seconds of denaturation at $94^{\circ} \mathrm{C}, 30$ seconds of annealing at $55^{\circ} \mathrm{C}$, and 1 minute and 30 seconds of extension at $72^{\circ} \mathrm{C}$ and single cycle of final extension at $72^{\circ} \mathrm{C}$ for 7 minutes. The PCR products were analyzed by restriction digestion using AluI, HhaI, KpnI, MseI, MspI and RsaI endonuclease according to the manufacturer's instructions. The resulting RFLP patterns were compared with those of reference strains; mulberry dwarf (MD), onion yellow (OY) and water dropwort witches' broom (WDWB) of previous data (Lee et al., 1998; Jung et al., 2002).

The 16S rDNA fragment was purified and sequenced with eight primers $(350 \mathrm{~F}, 350 \mathrm{R}, 788 \mathrm{~F}, 920 \mathrm{R}$, 1099F, 1505F, SN910601 and SN011119) that have been used to sequence phytoplasma $16 \mathrm{~S}$ rDNA and $16 \mathrm{~S}-23 \mathrm{~S}$ rDNA spacer region (SR) (Jung et al., 2003). Comparison of 16S rDNA sequence of Myanmar isolate (SP-MYAN) with those archived in the nucleotide sequence database of the National Center for Biotechnology Information (NCBI) was performed using the BLAST program (Altschul et al., 1990). The sequences were aligned with those of most phytoplasmas reported to date and sequence similarities were evaluated using the GENETYX-WIN package, version 3 (Software Development, Tokyo, Japan). For phylogenetic analysis, 16S rDNA sequences from 30 ' $C a$. Phytoplasma' species, SP-MYAN and Acholeplasma laidlawii were aligned using Clustal W (Thompson et al., 1994). A phylogenetic tree was constructed by neighbor-joining method (Bootstrap 

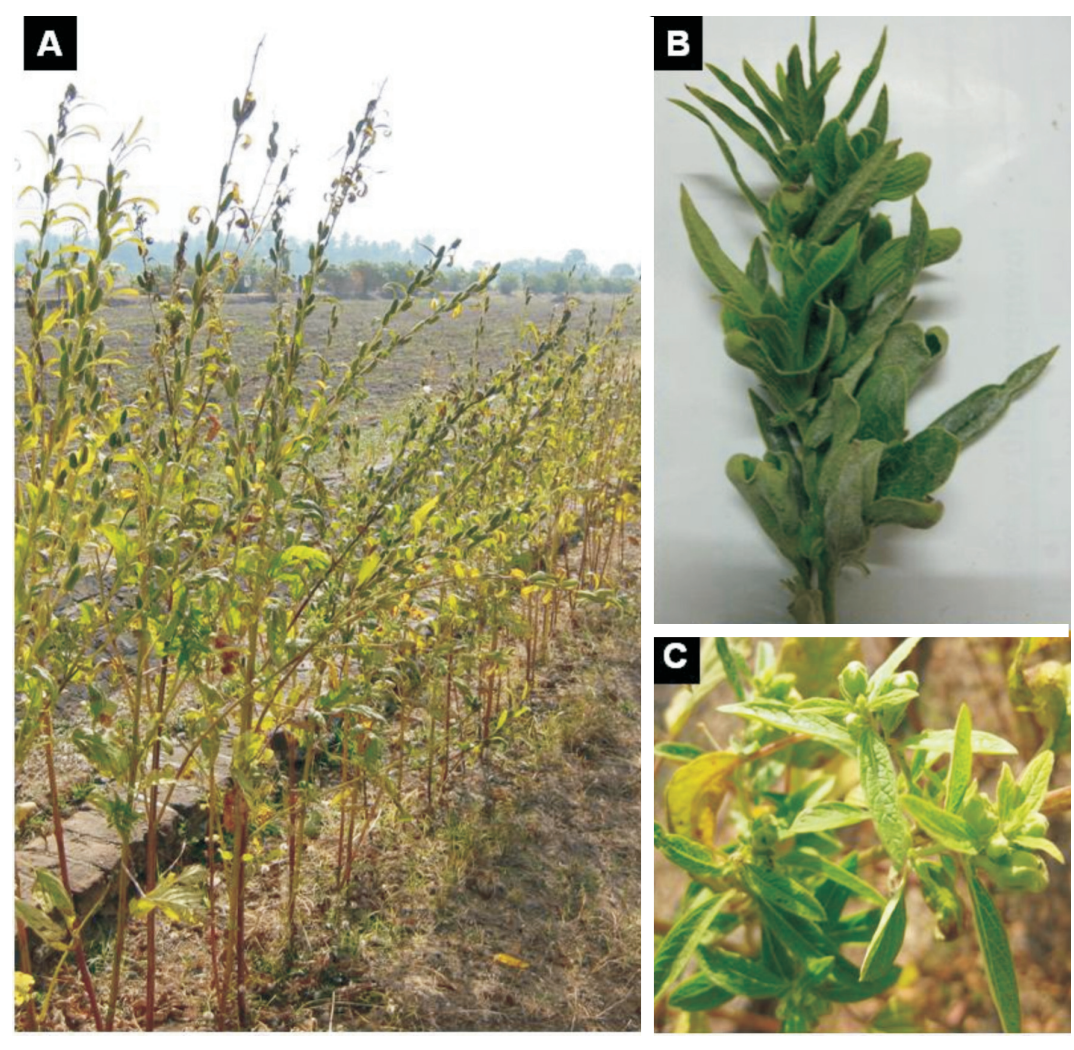

FIGURE 1 - Phyllody symptom of sesame plants: A. phyllody affected plants in the field; B. a shoot showing internodes shortening with dense leaves and $\mathrm{C}$. shoots showing green leaflike floral organs.

analysis with 100 replicates) and the tree was viewed by using TREEVIEW (Page, 1996). Acholeplasma laidlawii was selected as the outgroup.

Amplification of phytoplasmal 16S rDNA fragments $(1.8 \mathrm{~kb})$ from the examined samples by a phytoplasma universal primer set revealed that the sesame plants showing phyllody symptom in Yezin area, Myanmar were infected by a phytoplasma designated SP-MYAN strain (data not shown). The phytoplasma strain was classified on the basis of RFLP analysis of PCR products primed by SN910601 and SN011119 according to the classification scheme established by Lee et al. (1998). RFLP profiles of SP-MYAN were identical to those of MD, OY and WDWB which were reported as aster yellows phytoplasmas (Jung et al., 2002; Kim \& Jung, 2007). Based on RFLP profiles with 6 restriction enzymes, the phytoplasma associated with phyllody disease in sesame plants was classified into 16SrIB group (Figure 2). The result was provided by Lee et al. (1998) that summarized pattern groups produced by RFLP analysis of $16 \mathrm{~S}$ rDNA from representative type strains of phytoplasmas.

Sequences from the five symptomatic samples were all identical and one of these sequences was deposited in the GenBank database. Blast search analysis of sequence data of SP-MYAN (AB558132) showed the highest (99\%) similarity with the following phytoplasmas: onion yellows (AP006628), mulberry yellow dwarf
(GQ249410), ash witches' broom (AY566302), silene virescence (AY744070) and barley deformation (AY734453), members of 'Candidatus phytoplasma asteris'. Moreover, the SP-MYAN phytoplasma had the greatest homology (99.6\%) with 16S rDNA sequence of sesame phyllody phytoplasma from India (DQ431843) (Khan et al., 2007). A phylogenetic tree was constructed based on $16 \mathrm{~S}$ rDNA plus SR sequences from the previously described ' $\mathrm{Ca}$. Phytoplasma' species, SP-MYAN and A. laidlawii (Figure 3). The phylogenetic analysis supported the results of sequence analysis data and RFLP analysis that SP-MYAN belonged to 16SrIB.

In Myanmar, phyllody symptoms in sesame plants have frequently been found in the fields; however, there is no evidence that the etiological agent is phytoplasma and also belongs to aster yellows group. This disease was reported previously in Israel (Klein, 1977), Oman (Al-Sakeiti et al., 2005), Thailand (Martini et al., 2007), Pakistan (Akhtar et al., 2008) and Turkey (Sertkaya et al., 2007). However, sesame witches' broom phytoplasma of Oman, and sesame phyllody phytoplasmas of Pakistan and Thailand have been assigned to a different phytoplasma group, peanut witches' broom group (AlSakeiti et al., 2005; Akhtar et al., 2008). On the other hand, sesame phyllody phytoplasma of Turkey isolate was reported as 'Ca. P. trifolii' (Sertkaya et al., 2007). 


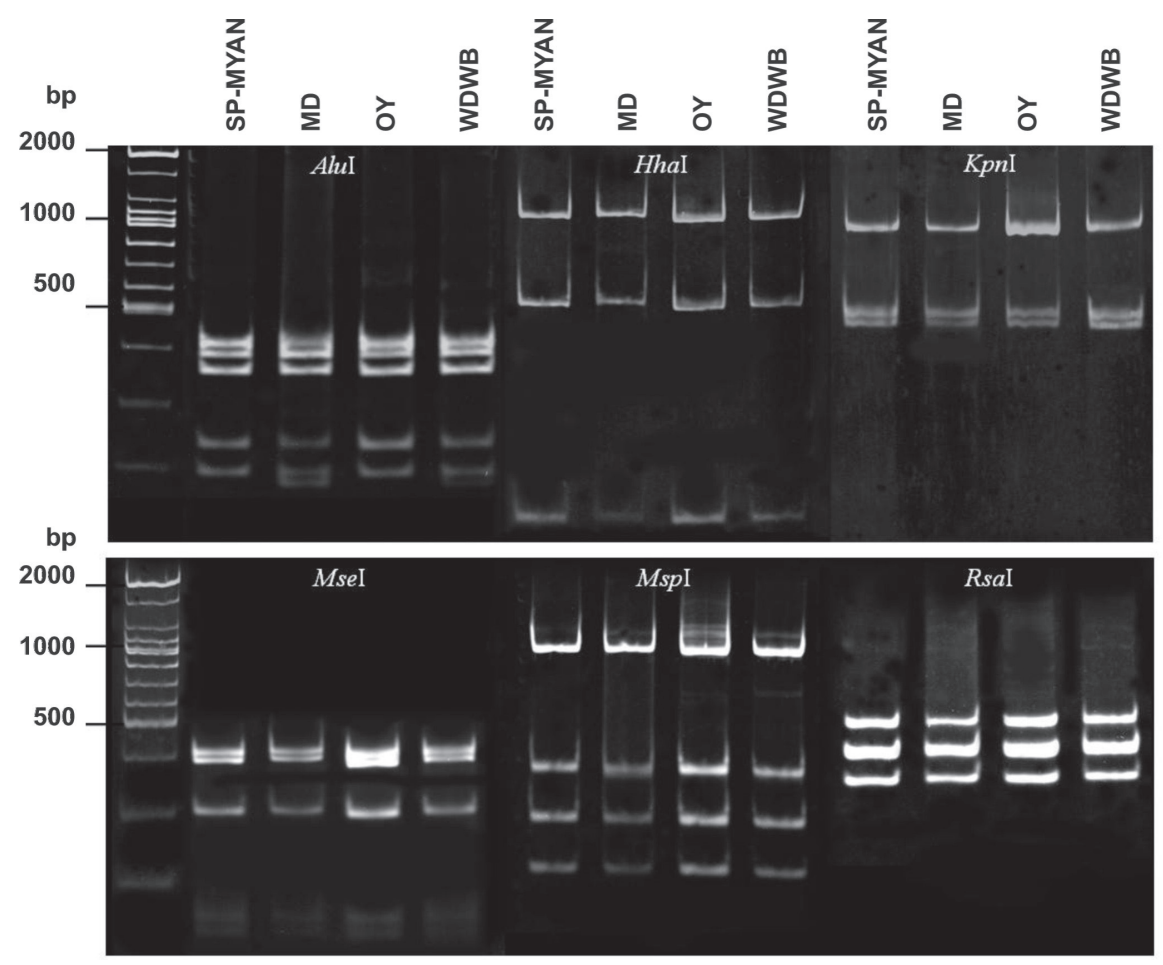

FIGURE 2 - AluI, HhaI, KpnI, MseI, MspI and RsaI restriction profiles of PCR products amplified with universal primers SN901601 and SN011119 of sesame phyllody phytoplasma (SPMYAN) in comparison with mulberry dwarf (MD), onion yellow (OY) and water dropwort witches' broom (WDWB). (Lane M: 100 bp plus DNA ladder).

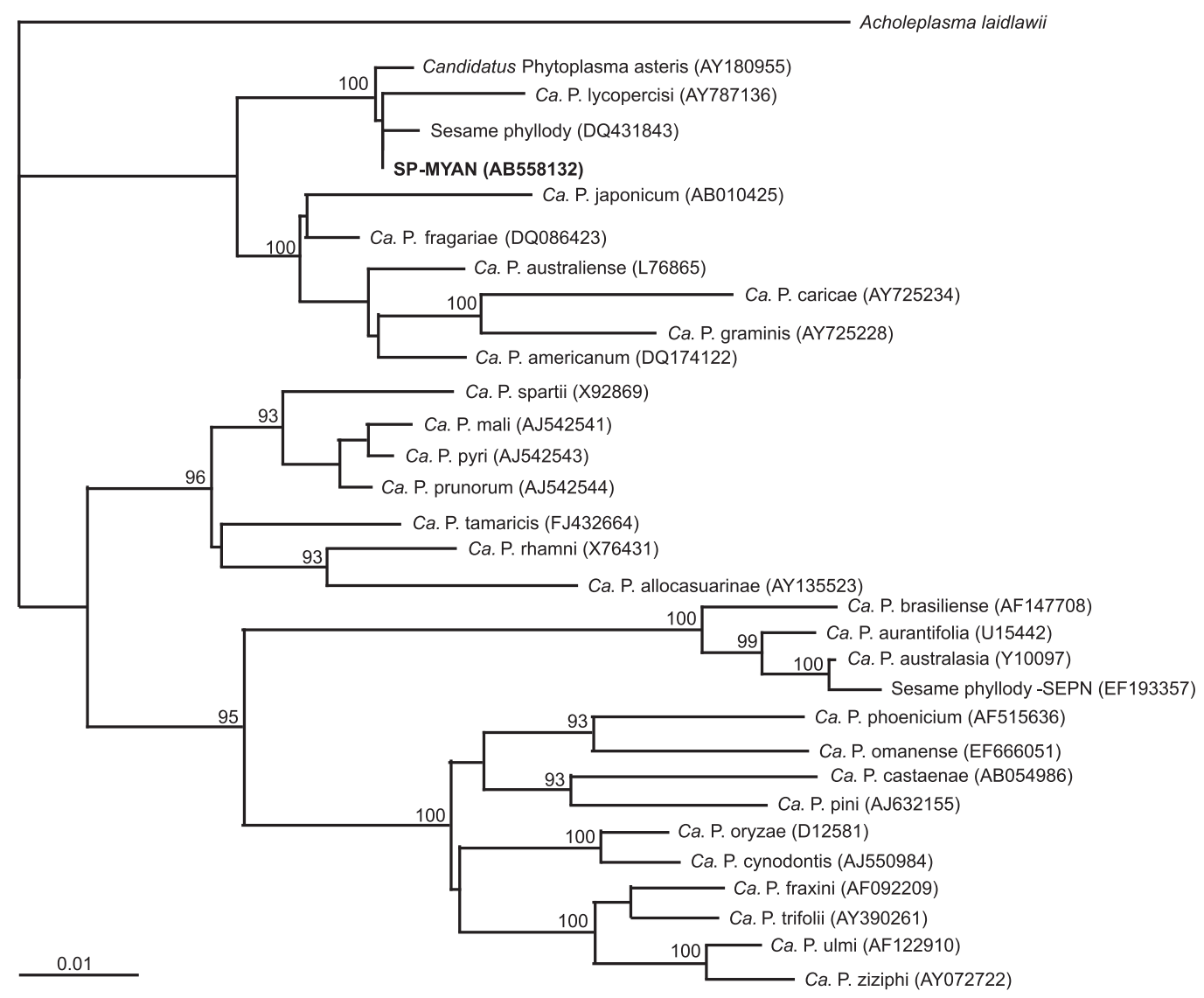

FIGURE 3 - Phylogenetic distance tree constructed by neighbor-joining method, comparing nearly complete 16S rDNA and SR sequence of sesame phyllody phytoplasma from Myanmar (SP-MYAN) with those of other phytoplasmas from GenBank. Acholeplasma laidlawii was used as an outgroup. Numbers on branches are bootstrap values obtained for 100 replicates (only values above $80 \%$ are shown). The bar represents a phylogenetic distance of $1 \%$. 
Therefore, classification of phyllody phytoplasma associated with sesame has been attributed to at least three distinct strains worldwide including aster yellows, peanut witches' broom and clover proliferation group (Al-Sakeiti et al., 2005; Khan et al., 2007). This study represents the first evidence of phytoplasma association with phyllody affected sesame plants related to ' $\mathrm{Ca}$. P. asteris' belonging to $16 \mathrm{SrI}-\mathrm{B}$ in Myanmar.

\section{ACKNOWLEDGMENTS}

This work was supported by the National Research Foundation of Korea (NRF) grant funded by the Korea government (MEST) (No.2009-0083845).

\section{REFERENCES}

Abraham E, Natarajan V, Murugaesanm K (1977) Damage by pests and phyllody to $S$. indicum in relation to time sowing. Madras Agriculture Journal 64:298-301.

Akhtar KP, Dickinson M, Sawar G, Jamil FF, Haq MA (2008) First report on the association of a $16 \mathrm{Sr}$ II phytoplamas with sesame phyllody in Pakistan. Plant Pathology 57:771.

Altschul SF, Gish W, Miller W, Meyers EW, Lipman DJ (1990) Basic local alignment search tool. Journal of Molecular Biology 215:403-410.

Al-Sakeiti MA, Al-Subhi AM, Al-Saady NA, Deadman ML (2005) First report of witches' broom disease of sesame (Sesamum indicum) in Oman. Plant Disease 89:530.

Favre R, Kyaw Myint (2009) An analysis of the Myanmar edible oil crops sub-sector. Rural infrastructure and Agro-industries division. Food and Agriculture Organization of the United Nation. Rome.

Jung HY, Woo TH, Hibi T, Namba S, Lee JT (2002) Phylogenetic and taxonomic status of the phytoplasmas associated with water dropwort (Oenanthe javanica DC) disease in Korea and Japan. The Plant Pathology Journal 18:109-114.

Jung HY, Sawayanagi T, Kakizawa S, Nishigawa H, Wei W, Oshima K, Miyata S, Ugaki M, Hibi T, Namba S (2003) 'Candidatus Phytoplasma ziziphi', a novel phytoplasma taxon associated with jujube witches' broom disease. International Journal of Systematic and Evolutionary Microbiology 53:10371041 .
Khan MS, Raj SK, Snehi SK (2007) First report of 'Candidatus phytoplasma asteris' affecting sesame cultivation in India. Journal of Plant Pathology 89:301-305.

Klein M (1977) Sesame phyllody in Israel. Plant Disease Reporter 54:735-738.

Lee I-M, Gudersen-Rindal DE, Davis RE, Bartoszyk IM (1998) Revised classification scheme of phytoplasmas based on RFLP analysis of $16 \mathrm{~S}$ rRNA and ribosomal protein gene sequences. International Journal of systematic Bacteriology 48:1153-1169.

Martini M, Lee I-M, Bottner KD, Zhao Y, Botti S, Bertaccini A, Harrison NA, Carraro L, Marcone C, Khan AJ, Osler R (2007) Ribosomal protein gene-based phylogeny for finer differentiation and classification of phytoplasma. International Journal of Systematic and Evolutionary Microbiology 57:2037-2051.

McCoy RE, Caudwell A, Chang CJ, Chen TA, Chiykowski LN, Cousin MT, Dale JL, De Leeuw GTN, Golino DA, Hackett KJ, Kirkpatrick BC, Marwitz R, Petzold H, Sinha RC, Sugiura M, Whitcomb RF, Yang IL, Zhu BM, Seemüller E (1989) Plant diseases associated with mycoplasma-like organisms. In: Whitcomb RF, Tully JG (Eds.) The Mycoplasmas. New York NY. Academic Press. pp. 545-560.

Nakashima K, Hayashi T, Chaleeprom W, Wongkaew P, Sirithorn P (1995) Detection of DNA of phytoplasmas associated with phyllody disease of sesame in Thailand. Annual Phytopathological Society of Japan 61:519-528.

Nakashima K, Chaleeprom W, Wongkaew P, Sirithorn P, Kato S (1999) Analysis of phyllody disease caused by phytoplasma in sesame and Richardia plants. Journal of Japan International Research Center for Agricultural Science 7:19-27.

Namba S, Kato S, Iwanamis S, Oyaizu H, Shiozawa H, Tsuchizaki $T$ (1993) Detection and differentiation of plant-pathogenic mycoplasmalike organism using polymerase chain reaction. Phytopathology 83:786-791.

Page RDM (1996) TREEVIEW: an application to display phylogenetic trees on personal computers. Computer Applications in the Biosciences 12:357-358.

Sertkaya G, Martini M, Musetti R, Osler R (2007) Detection and molecular characterization of phytoplasmas infecting sesame and solanaceous crops in Turkey. Bulletin of Insectology 60:141-142.

Thompson JD, Higgins DG, Gibson TJ (1994) CLUSTAL W: improving the sensitivity of progressive multiple sequence alignment through sequence weighting, position specific gap penalties and weight matrix choice. Nucleic Acids Research 22:4673-4680. 